\title{
Assessment of level of quality of property insurance within the scope of protection against ecological risks in Poland with the use of the SERVQUAL method. Research results
}

\author{
JAROSŁAW W. PRZYBYTNIOWSKI ${ }^{1}$ (iD https://orcid.org/0000-0001-6164-2953 \\ Institute of Management, the Jan Kochanowski University
}

\begin{abstract}
The article addresses the issue of ecological insurance. Its aim is the assessment of the level of the quality of property insurance services within the scope of protection against ecological risks by individual clients in Poland (from the Podkarpackie, Świętokrzyskie and Małopolskie voivodeships). The SERVQUAL method was used to measure the quality of services provided by insurance companies.

The analyses showed that ecological insurance is practically non-existent on the Polish market even though protection against ecological risks is offered by 25 insurance companies $(78.1 \%)$.

The survey research was carried out among 450 respondents - clients of insurance companies in years 2015, 2016 and 2017. The results indicate the reluctance of individual clients to conclude insurance contracts. The SERVQUAL indicators are at the level below the proposed critical point of .00, which indicates the lack of the so-called quality optimum.
\end{abstract}

Paper type: research article

Key words: ecological insurance, ecological damage, quality of service, SERVQUAL, insurance service.

\footnotetext{
1 j.w. przybytniowski@wp.pl
} 


\section{Introduction}

The concepts of ecological damage and ecological insurance are associated with the reflections on property insurance relating to environmental protection and the specifics of this type of insurance.

Ecological insurance deals with the mitigation of the effects of various risks associated with environmental pollution, caused by the activity of the elements and forces of nature (e.g. fire, water, etc.), or the activity of humans (e.g. effects of equipment failures, etc.). In both cases, the effect of risks is the threat to the environment ecosystem balance. On the other hand, ecological risks (Fiedor, 2007) are connected with activities which cause adverse changes in the natural environment and differ significantly in scope and degree of impact, ranging from sudden occurrences, such as accidents or failures to long-term phenomena, such as the destruction of construction infrastructure as a result of landslides, adverse impact on the health of the population. Due to the diversity of ecological risks, they can be divided into strictly ecological risks (environmental risks), i.e. the possibility of deterioration of the quality of the environment, disruption of natural balance or natural disaster, and the largely-understood risks including health, cultural, material and financial risks (Sordyl \& Płonka, 2010).

For this risk type, it is often impossible to compensate for damage not only in relation to specific people, but also objects. Thus, in accordance with the current law there is a rule stating that "the polluter is the one who pays." This means that the perpetrator is financially responsible for the damage caused to the environment (Adamowicz, 2004). Therefore, ecological damage can be treated as damage:

- to the environment - destruction of natural assets that constitute the elements of the environment,

- to a person - death, personal injury, and health impairment,

- to property - destruction or damage to tangible assets, consumer or production property, and

- loss of benefits.

Clients of property insurance companies, being aware of the threats surrounding them and the possibility of environmental damage, often leading to high losses in life and property, seek protection against negative consequences of accidents. Insurance practice shows that not all risks can be predicted, let alone prevented. Therefore, the client decides to secure themselves against a random event by concluding an insurance contract (Przybytniowski, 2013b). The insurance is intended to provide the client with a sense of security in case an insurance accident happens, through the possibility of removing the effects of the damage based on the legal liquidation procedures.

The aim of the study is the assessment of the level of the quality of property insurance services within the scope of protection against ecological risks by clients 
from the Podkarpackie, Świętokrzyskie and Małopolskie voivodeships. To measure the quality level of the insurance service, the SERVQUAL method was used to determine the level of dissonance (gap) that arose between what the client expects and what is actually provided within the ecological insurance. This allows the property insurance company to recognize the directions of improvement of the services offered and facilitates the pro-development decision-making by the management of the insurance company.

The formulated problem requires a holistic approach which accounts for the analysis of the offer of property insurance companies regarding the scope of protection against ecological risks and the ecological awareness of individual clients.

\section{Environmental awareness}

The issues related to environmental protection and, as a consequence, the related issue of ecological awareness of the society are analysed by researchers. Due to the current lack of a uniform and widely accepted definition of ecological awareness, one can find different terms describing it in the literature of the subject (Hadzigeorgiou \& Skoumios, 2013; Kiełczewski, 1999; Krajewski, 2018; Sederevičiūtè-Pačiauskienè, Žilinskaitè-Vytienè, \& Valantinaite, 2017), i.e.:

- ecological knowledge - knowledge and understanding of the ways of cooperation and coexistence of nature and man,

- ecological sensitivity,

- emotional attitude to nature,

- pro-ecological attitude,

- actions taken within the scope of environmental protection.

Ecological awareness can be defined as a human attitude to nature. It results from knowledge not only about nature, but also about related sciences and the determination to keep it intact (in the original state). It manifests itself mainly through: respect for nature, counteracting environmental threats, as well as, and perhaps above all, complying with legal provisions related to environmental protection. According to Burger (2000), ecological awareness is associated with a descriptive category with a complex structure. It belongs to a set of pieces of information and beliefs related to the natural environment. It concerns the perception of the existing relationships between the state and nature of the environment, and the conditions and quality of human life. This is an ambiguous approach, directed at and assigned to the public, creating an area of social awareness (Wódz \& Wódz, 1993). This area can be referred to the natural environment, and it manifests itself mainly through: thinking, experiencing, understanding and valuing the places where living organisms reside. 
Ecological awareness can be understood in a wider and narrower sense (Bohdanowicz, 2006):

- in a wider sense - it is (...) the entirety of the recognized ideas, values and opinions about the natural environment and human (social) development, common for specific groups in a given historical period,

- in a narrower sense - it is (...) the state of the knowledge and ideas of people about the role of the environment in human life, its anthropogenic burden, the degree of depletion, threats and protection, including the state of the knowledge on methods and instruments of control and use, as well as the protection of the environment.

In a broader sense, this concept is used as a whole of recognized values and opinions about the environment, as the human development and place of life (society), and in a narrower (more axiological) sense - the state of knowledge, ideas and views of people about the role of the environment in society and the knowledge about tools and methods of management, shaping and protection of the environment (Górka, Poskrobko, \& Radecki, 1998).

Ecological awareness is treated as a multidimensional concept. Thus, in the literature of the subject, where one can encounter the reflections on ecological consciousness, the attention is paid to its various types, which were formed on the basis of the relationship between the natural environment and man. These are among others:

- The so-called biblical I - man is a being and nature is subordinate to him and created for him ( $\mathrm{Rdz} 1,26-27)$.

- The so-called biblical II - human domination over nature changes in constant cooperation with it through work ( $\operatorname{Rdz} 3,17-18)$.

- Relating to conservation - where the conservation attitude was formed through the spread of human activity in the natural environment (Broda \& Pluskiewicz, 1993).

- Zero-growth - which determines the ideological direction assuming anti-development in the field of urbanization, technology and scientific research, where the goal is to avoid the disaster of the natural environment in connection with humans (www.slownik-online).

The above-analysed types of ecological awareness indicate clearly the man's desire to become independent of nature. It is impossible because nature and people are part of the environment.

As Papuziński (2006) writes, ecological awareness is not only knowledge, ideas or views about the environment. It is a paradigm containing values, ideas and opinions related to the environment in which a particular person lives, works and acts identically as in the whole society. However, according to Kalinowska (2013), the concept is rather ambiguous, and is related to the three levels of mental states:

- an intuitive conviction that the existence of an element is at risk in a situation where health and human needs are at risk (Krajewski, 2018); 
- an intuitive conviction that they can be associated with knowledge related to threat mechanisms;

- emotional reactions to the observed reality.

In the scientific discourse ecological awareness is defined as a form of social awareness, which manifests itself in the thinking and experiences of individual people, as well as socially functioning norms related to the understanding and valuation of the environment (Zecha, 2010). Looking from the perspective of an individual - this awareness is the result of the socialization process in which each of us participates throughout their conscious life. It is a subjective phenomenon, which consists in the mutual complementation of ecological knowledge and imagination. The development and shaping of ecological awareness in humans can be depicted in three stages as (Frątczak, 2001):

- Ordinary - based on verified opinions and information.

- Ideological - mainly encountered among activists of ecological movements and organizations (knowledge based primarily on existing views).

- Common - scientific, shaped as a result of acquired upbringing and knowledge.

Everyone's ecological awareness is shaped during a complex process as a result of the generally accepted and successively changing social norms, informal and formal ecological education (Poskrobko, 2007), information contained in the mass media and the activities of the country. This awareness is also dependant on the place of residence. In the inhabitants of heavily degraded areas, ecological awareness is born under the influence of observation of the adverse effects on the natural environment. However, in the inhabitants of protected areas, this awareness develops mainly under the influence of their own positive observations, as well as a result of positive opinions expressed by residents and tourists of other regions (Bailey, Swinerd, Lewis, \& Crowther, 2010).

In Poland, pioneering and, at the same time, comprehensive research devoted to the issue of ecological awareness was carried out in the Tarnobrzeg region in 1983 (Fudali, 2002). It was found that people focus more on activities that directly threaten people, e.g. in the situation of contamination of drinking water in a specific place, rather than "distant" threats, e.g. threats related to the condition of forests as a result of the activity of pests or felling, which may result in climate changes. In addition, it was agreed that people treat the natural environment as value, but do not feel the need for any action for its sake (Kłos, 2015). 


\section{Ecological risks, damage and insurance}

In the literature one can find a narrower approach to environmental insurance, represented by Labatt and White (2002) and a wider approach represented by Maśniak (2003). In a narrower sense, ecological insurance is understood as “(...) a legal instrument whose pro-ecological nature regarding mining, nature, functions and purpose are closely related to the responsibility of entities for environmental damage" (Sordyl \& Płonka, 2010). In a broader sense, ecological insurance covers both the civil liability of entities for ecological damages and the insurer's liability for losses incurred related to their experience as part of property insurance of the injured person. In the case of the advanced types of environmental insurance, the insurance covers the civil liability of the perpetrator, material damage, and the lost benefits of the injured resulting from a specific "ecological" event, that is a source of losses, which is extremely important in a situation where it is not possible to attribute fault to specific persons responsible for the damage.

The basic problem in the case of environmental damage is the concept of an insurance accident which makes a given event quality for the insurance coverage. This concept is understood as a "sudden" and "unpredicted" random event. Ecological damage is often characterized by the "lack of suddenness," which excludes most of them from the insurance coverage (Łabno, 1995). Such consequences can often also be expected - hence the lack of "unpredictability." This problem has been eliminated by the United States that introduced changes to insurance legislation. The unpredictable and sudden nature of the insurance event were abandoned there. Instead, the insurance coverage against damage to the environment was extended (Łabno, 1995) (Commercial Land Insurance Policy and Pollution Legal Liability Site Guard Policy in the United Kingdom, while in the United States Pollution Legal Liability was introduced). Doś (2007) assumed that ecological insurance is closely related to the source of the risk, not the scope of insurance protection. By assuming the same, one can adopt a broad definition of environmental insurance and include in its scope property insurance or lost benefits in addition to liability insurance (Doś, 2007).

\section{The scope of protection against ecological risks in selected insurance products in Poland}

The analysis of voluntary insurance contracts which property insurance companies offer to their individual clients in Poland regarding the insurance against the consequences of environmental risks indicates that there are no such contracts on the Polish market. One contract which in its package contains risks, such as hurricane, flood and fire was identified. This is the insurance from fire and other random events (Przybytniowski \& Pacholarz, 2016). On the other hand, typical civil liability 
insurance limits its scope only to protection of damage caused to third parties and additionally caused only by sudden and unexpected emission of pollution. They do not cover the costs of land reconstruction, restoring biological balance, or damage resulting from slow and long-term contamination. In addition, the responsibility for environmental disasters can also be unknowingly transferred, for example by taking over or buying a company that is struggling with these types of problems.

It should be emphasized that the ecological liability of business entities should be the function and purpose of ecological insurance. Therefore, insurers should assume part of the responsibility by offering companies the adequate insurance coverage. From the point of view of the clients of insurance companies, it is reasonable to expect protection from the two types of liability - civil and administrative.

The analysis of insurance products can be made using the criteria that are related to: scope of insurance protection (types of random events whose occurrence makes the insurance company liable), subject of insurance protection (type of protected resources or civil liability) and the nature of the event and its consequences (parameter characteristic for inheriting environmental risk by insurance companies) (Przybytniowski, 2013a).

When analysing the Polish market of ecological insurance services, the authors paid attention to the criterion referring primarily to the scope of risk, including selected products, insurance for: civil liability, households and apartments.

The scope of protection against ecological risk is offered by 25 insurance companies (78.1\% of the total on the Polish property insurance market). Only two insurance companies: AXA SA and Signal Iduna SA do not offer services related to housing protection. The basic scope of the insurance contract offered by insurers is the guarantee of compensation in the event of flooding due to precipitation and the adverse effects of nuclear energy or radioactive contamination, laser and maser radiation, as well as magnetic and electromagnetic fields (this scope is offered by 18 (56.2\%) insurance companies).

On the opposite pole there are contracts protecting households and apartments that have in-wall, in-ceiling or in-floor elements of installations affected by atmospheric discharges or surges, as well as the protection against damage caused by waste storage (4 insurance companies). Bearing in mind the scope of the third-party liability insurance relating to electrical and electronic equipment, the guarantee of protection covers the effects of the activity of nuclear energy, laser and maser radiation, ionizing radiation, magnetic or electromagnetic fields and contamination as well as temperature, gas and vapour (this scope is offered by $10,31.3 \%$ of insurance companies). However, six of these companies (18.8\%) protect against damage caused indirectly or directly by emission, leakage, release and other form of release of dangerous substances into the air, soil and water.

Bearing in mind insurance against fire and other random events, 25 (78.1\%) of insurers were analysed, of which only 13 (40.6\%) offer products containing protection against environmental risks, including: activities related to nuclear energy or 
radioactive destruction, and resulting from earthworks, hail, snow, rain due to poor technical condition.

Another type of insurance, which was subject to analysis, referred to environmental damage as part of motor insurances: civil liability and autocasco insurance, where insurers protect against damage related to the transport of dangerous goods. Over half of insurance companies conducting insurance activities in Poland provides protection against damage caused to the natural environment and by the activities of natural forces. Four insurance companies: Warta SA, Concordia Polska SA, Interrisk SA, TUW TUW offer products protecting against damages caused by nuclear energy and radioactive substances. Autocasco insurance, in relation to protection against ecological risks, is present in the offer of $21(65.6 \%)$ insurers. In its scope, this type of insurance protects against improper loading, transport and unloading of cargo and luggage, as well as against radioactive contamination (13 (40.6\%) of insurers), nuclear energy (12 (37.5\%) of insurers). Only $4(12.5 \%)$ insurance companies protect against damage caused by laser or maser radiation as well as by magnetic or electromagnetic fields.

\section{Research methodology}

The research concerned the assessment of the level of the quality of property insurance services by individual clients from the Podkarpackie, Świętokrzyskie and Małopolskie voivodeships.

The SERVQUAL method was used to measure the level of the quality of the insurance service. This method is used as a universal way to study the perceived quality of various types of services. It identifies the difference between what the client actually experiences and what they expect to receive during the service delivery process (Parasuraman, Zeithaml, \& Berry, 1985). With the help of this method, insurance companies can anticipate the expectations of their current and potential customers and identify the assessment of the quality of the services offered to them in accordance with the following mathematical equation.

$$
S=\sum(P-O)
$$

where:

$S$ - result of SERVQUAL,

$P$ - perceived quality of service,

$\boldsymbol{O}$ - expected quality of service.

The presented model of the insurance service quality is focused on the subjective assessment of the quality by clients. The SERVQUAL method relates to five areas: infrastructure, quickness, completeness, reliability and empathy. Each of these areas is 
assigned a list of 22 statements to assess the expectations of the individual client and the degree to which they think these expectations are met. The questionnaire contains a question about the importance of each of the areas of the service quality for the service recipient. In addition, the questionnaire contained questions regarding:

- the assessment of the quality of the service provided,

- the knowledge of the risks associated with the insurance protection in the event of weather anomalies and insurance companies offering this type of protection,

- decisions on mitigating the financial consequences of catastrophic events,

Data were collected through interviewers in periods from August to October in years 2015, 2016 and 2017 among individual clients who have a property insurance agreement concluded in three voivodeships: Świętokrzyskie, Małopolskie and Podkarpackie.

The property insurance companies meeting the following criteria were selected for the study:

- available service level assessments for at least three years,

- the same property insurance companies had branches (or representative offices) in all three studied voivodeships.

The sample size consisted of a total of 450 respondents, of which: 191 (42.4\%) respondents were from the Świętokrzyskie Voivodeship, 98 (21.8\%) from the Małopolskie Voivodeship, and 161 (35.8\%) from the Podkarpackie Voivodeship (Table 1).

This ensured quasi-representativeness of the results for the population of Poland 18+, taking into account: gender and place of residence. Additional factors were also taken into consideration during the selection process:

- indication of the insurance company with which one has concluded the property insurance agreement against fire, other random events and civil liability,

- satisfaction or dissatisfaction with the conclusion of the property insurance agreement against fire, other random events and civil liability,

- satisfaction or dissatisfaction with the elimination of damage from the property insurance agreement against fire, other random events and civil liability,

- continuation or failure to continue the insurance contract in a property insurance company.

Table 1 Respondents from specific voivodeships

\begin{tabular}{|l|c|c|c|c|c|c|c|}
\hline \multirow{2}{*}{ Voivodeship } & \multicolumn{2}{|c|}{2015} & \multicolumn{2}{c|}{2016} & \multicolumn{2}{c|}{2017} & Average \\
\cline { 2 - 8 } & Number & \% & Number & \% & Number & \% & $\%$ \\
\hline Małopolskie & 31 & 20.67 & 33 & 22.15 & 34 & 22.52 & 21.78 \\
\hline Podkarpackie & 54 & 36.00 & 52 & 34.90 & 55 & 36.42 & 35.77 \\
\hline Świętokrzyskie & 65 & 43.33 & 64 & 42.95 & 62 & 41.06 & 42.45 \\
\hline
\end{tabular}




\section{Research results}

Bearing in mind the subject matter and purpose of the research presented at the beginning, one of the basic questions asked to clients referred to the general assessment of property insurance services provided by employees of insurance companies in the voivodeships examined.

The highest assessment scores were obtained in the Świętokrzyskie voivodeship, where the average of positive assessments from three years amounted to $42.5 \%$, of which the most active county was Sandomierz County, from where the majority of respondents came - almost $66.1 \%$. The Podkarpackie Voivodeship (the average of three years $-35.8 \%$ ) was the next one and here Tarnobrzeg County with nearly $73 \%$ was the active county. The reason for the activity of residents living in these areas were floods and hurricanes that hit these areas in the last ten years. The lowest percentage of active respondents willing to answer the questions in the questionnaire - was recorded in the Małopolskie voivodeship - the average of three years was $21.8 \%$. Bearing in mind the locations, the highest percentage of people responding to survey questions came from rural areas near the city. People living in the countryside were the next. On the other hand, people living in cities were reluctant.

Respondents answered a question referring to the knowledge about ecological threats related to the occurrence of weather anomalies. The respondents most often mentioned the flood among the risks that appear in the insurance package against fire, other random events and third-party liability. This risk was indicated by over $91.2 \%$ of respondents in 2017. This ratio increased in relation to 2015 by 1.5 percent. Other risks mentioned by the respondents were water supply damage (67.1 and increased by $2.5 \%$ in relation to 2015), which in a significant way, as indicated by respondents - affects the protection of the environment. The opposite pole lists: landslides (2.9\%), overvoltages caused by atmospheric discharge $(6.8 \%)$ and floodings $(7.2 \%)$.

The respondents were also to assess the insurance company whose services they were using (on a scale from 1 to 6 , where 1 meant the least satisfied, and 6 - the most satisfied). They assessed the quality of customer service, especially in terms of: elimination of damage, professionalism of employees of insurance companies, and, consequently, the decision to continue or discontinue the insurance contract. The authors were looking for the answer to the question whether there is a correlation between the level of customer service quality and their decision to continue or discontinue the insurance agreement.

Every fourth respondent evaluating particular insurance companies regarding ecological insurance, pointed to Ergo Hestia, assessing it positively (29.6\%) when it comes to elimination of damage and professionalism of employees and declaring the willingness to continue the insurance coverage by this company. The 
assessment in relation to the research which took place in 2015 changed in favour of this company by $2.6 \%$. A lack of satisfaction was indicated by $9.4 \%$ and this indicator remains practically unchanged compared to 2015.

The subsequent companies to receive a positive rating were Warta and Allianz with, at the same time, a low rate of negative ratings. However, on the opposite pole, considering the elimination of flood damage and more, clients pointed to: Link4 (2.1\%), with a high negative assessment score indicator. It is worth noting that PZU, with $8.2 \%$, was in the middle of the list of the analysed insurance companies in terms of positive ratings, while a fairly high negative rating rate $(31.5 \%)$ placed this insurance company the last on the list. This rating, as it resulted from the research, was mainly influenced by the process of the elimination of damages and the approach to clients by the employees of this company. As a result - the majority of respondents declared the change of the insurer. Other insurance companies that clients also listed include: Allianz, Compensa, Generali, UNIQA.

The next stage of the research was an attempt to determine the factors related to the quality of the service provided and continuation of insurance in the same insurance company. The most important factors turn out to be: professionalism of employees of the insurance company and assistance in elimination of damage (Tables 2, 3).

As the data in Table 2 show, there is a relationship between the professionalism of the employee and the continuation of the insurance contract. At the same time, which is puzzling, during the analysed period, the professionalism of employees of the insurance company systematically deteriorated (a decrease of nearly $5 \% \mathrm{com}$ pared to 2015).

Table 2 Professionalism of an insurance company employee as a decisive factor about the continuation of the insurance contract

\begin{tabular}{|c|c|c|c|c|c|c|c|c|c|}
\hline \multirow{3}{*}{ Specification } & \multirow{2}{*}{\multicolumn{3}{|c|}{$\begin{array}{c}\begin{array}{c}\text { Professionalism } \\
\text { of the broker }\end{array} \\
2015\end{array}$}} & \multirow{2}{*}{\multicolumn{3}{|c|}{$\begin{array}{c}\begin{array}{c}\text { Professionalism } \\
\text { of the broker }\end{array} \\
2016\end{array}$}} & \multirow{2}{*}{\multicolumn{3}{|c|}{$\begin{array}{c}\begin{array}{c}\text { Professionalism } \\
\text { of the broker }\end{array} \\
2017\end{array}$}} \\
\hline & & & & & & & & & \\
\hline & Value & df & $\begin{array}{l}\text { Asymptotic } \\
\text { significance } \\
\text { (two-sided) }\end{array}$ & Value & df & $\begin{array}{l}\text { Asymptotic } \\
\text { significance } \\
\text { (two-sided) }\end{array}$ & Value & df & $\begin{array}{l}\text { Asymptotic } \\
\text { significance } \\
\text { (two-sided) }\end{array}$ \\
\hline $\begin{array}{l}\text { Pearson Chi- } \\
\text {-Square }\end{array}$ & 42.763 & 1 & .00 & 42.656 & 1 & .00 & 42.556 & 1 & .00 \\
\hline $\begin{array}{l}\text { Linear relation- } \\
\text { ship test }\end{array}$ & 42.515 & 1 & .00 & 42.501 & 1 & .00 & 42.494 & 1 & .00 \\
\hline $\begin{array}{l}\mathrm{N} \text { of significant } \\
\text { observations }\end{array}$ & \multicolumn{3}{|c|}{150} & \multicolumn{3}{|c|}{149} & \multicolumn{3}{|c|}{151} \\
\hline
\end{tabular}


The analysis of the data from Table 3 indicates that during the analysed period among respondents in general, there is a statistically significant relationship between assistance in the process of the elimination of damage and the choice of services of a specific insurance company. At the same time, it is noted that during the period analysed the assessment of assistance in the process of the elimination of damage as part of ecological insurance has systematically improved (an increase of $3.5 \% \mathrm{com}$ pared to 2015).

Table 3 Insurance company employee and assistance with the elimination of damage as a decisive factor about the continuation of the insurance contract

\begin{tabular}{|c|c|c|c|c|c|c|c|c|c|}
\hline \multirow{3}{*}{ Specification } & \multirow{2}{*}{\multicolumn{3}{|c|}{$\begin{array}{c}\text { Assistance in elimination } \\
\text { of damage }\end{array}$}} & \multirow{2}{*}{\multicolumn{3}{|c|}{$\begin{array}{c}\text { Assistance in elimination } \\
\text { of damage }\end{array}$}} & \multirow{2}{*}{\multicolumn{3}{|c|}{$\begin{array}{c}\begin{array}{c}\text { Assistance in elimination } \\
\text { of damage }\end{array} \\
2017\end{array}$}} \\
\hline & & & & & & & & & \\
\hline & Value & df & $\begin{array}{l}\text { Asymptotic } \\
\text { significance } \\
\text { (two-sided) }\end{array}$ & Value & df & $\begin{array}{l}\text { Asymptotic } \\
\text { significance } \\
\text { (two-sided) }\end{array}$ & Value & df & $\begin{array}{l}\text { Asymptotic } \\
\text { significance } \\
\text { (two-sided) }\end{array}$ \\
\hline $\begin{array}{l}\text { Pearson Chi- } \\
\text {-Square }\end{array}$ & 7.821 & 1 & .005 & 7.846 & 1 & .005 & 7.848 & 1 & .005 \\
\hline $\begin{array}{l}\text { Linear relation- } \\
\text { ship test }\end{array}$ & 7.769 & 1 & .005 & 7.787 & 1 & .005 & 7.786 & 1 & .005 \\
\hline $\begin{array}{l}\mathrm{N} \text { of significant } \\
\text { observations }\end{array}$ & \multicolumn{3}{|c|}{150} & \multicolumn{3}{|c|}{149} & \multicolumn{3}{|c|}{151} \\
\hline
\end{tabular}

In order to confirm the relationship between factors related to the quality of environmental insurance services and the assessment of the professionalism of employees of insurance companies, the SERVQUAL method was used. The general SERVQUAL indicators calculated showed that each of the five assessed areas defining the quality of property insurance services in the examined period was assessed negatively by respondents (Tables $4,5,6$ ).

Table 4 General SERVQUAL indicator non-weighted and weighted for the specifically analysed areas of the Matopolskie voivodeship ( $N=98)$ in 2015, 2016 and 2017

\begin{tabular}{|l|c|c|c|c|c|c|}
\hline \multirow{2}{*}{ Areas } & \multicolumn{2}{|c|}{2015} & \multicolumn{2}{c|}{2016} & \multicolumn{2}{c|}{2017} \\
\cline { 2 - 7 } & $\begin{array}{c}\mathrm{S}_{\mathrm{n}} \text { (non- } \\
\text {-weighted) }\end{array}$ & $\begin{array}{c}\mathrm{S}_{\mathrm{w}} \\
\text { (weighted) }\end{array}$ & $\begin{array}{c}\mathrm{S}_{\mathrm{n}} \text { (non- } \\
\text {-weighted) }\end{array}$ & $\begin{array}{c}\mathrm{S}_{\mathrm{w}} \\
\text { (weighted) }\end{array}$ & $\begin{array}{c}\mathrm{S}_{\mathrm{n}} \text { (non- } \\
\text {-weighted) }\end{array}$ & $\begin{array}{c}\mathrm{S}_{\mathrm{w}} \\
\text { (weighted) }\end{array}$ \\
\hline Infrastructure & -0.29 & -3.51 & -0.29 & -3.47 & -0.31 & -3.99 \\
\hline Quickness & -0.72 & -17.22 & -0.68 & -17.05 & -0.68 & -17.76 \\
\hline Reliability & -0.71 & -19.09 & -0.70 & -18.84 & -0.69 & -18.63 \\
\hline
\end{tabular}




\begin{tabular}{|l|c|c|c|c|c|c|}
\hline \multirow{3}{*}{ Areas } & \multicolumn{2}{|c|}{2015} & \multicolumn{2}{c|}{2016} & \multicolumn{2}{c|}{2017} \\
\cline { 2 - 7 } & $\begin{array}{c}\mathrm{S}_{\mathrm{n}} \text { (non- } \\
\text {-weighted) }\end{array}$ & $\begin{array}{c}\mathrm{S}_{\mathrm{w}} \\
\text { (weighted) }\end{array}$ & $\begin{array}{c}\mathrm{S}_{\mathrm{n}} \text { (non- } \\
\text {-weighted) }\end{array}$ & $\begin{array}{c}\mathrm{S}_{\mathrm{w}} \\
\text { (weighted) }\end{array}$ & $\begin{array}{c}\mathrm{S}_{\mathrm{n}} \text { (non- } \\
\text {-weighted) }\end{array}$ & $\begin{array}{c}\mathrm{S}_{\mathrm{w}} \\
\text { (weighted) }\end{array}$ \\
\hline Certainty & -0.58 & -13.34 & -0.58 & -14.03 & -0.58 & -14.00 \\
\hline Empathy & -0.35 & -4.87 & -0.29 & -3.48 & -0.25 & -2.47 \\
\hline \multirow{5}{*}{} & $\begin{array}{l}\text { Total } \\
\text { SERVQUAL } \\
=-0.529\end{array}$ & $\begin{array}{l}\text { Total } \\
\text { SERVQUAL } \\
=-11.606\end{array}$ & $\begin{array}{l}\text { Total } \\
\text { SERVQUAL } \\
=-0.509\end{array}$ & $\begin{array}{l}\text { Total } \\
\text { SERVQUAL } \\
=-11.373\end{array}$ & $\begin{array}{l}\text { Total } \\
\text { SERVQUAL } \\
=-0.502\end{array}$ & $\begin{array}{l}\text { Total } \\
\text { SERVQUAL } \\
=-11.370\end{array}$ \\
\cline { 2 - 7 }
\end{tabular}

Table 5 General SERVQUAL indicator non-weighted and weighted for individual areas of the Podkarpackie voivodeship ( $N=161$ ) in 2015, 2016 and 2017

\begin{tabular}{|l|c|c|c|c|c|c|}
\hline \multirow{2}{*}{ Areas } & \multicolumn{2}{|c|}{2015} & \multicolumn{2}{c|}{2016} & \multicolumn{2}{c|}{2017} \\
\cline { 2 - 7 } & $\begin{array}{c}\mathrm{S}_{\mathrm{n}} \text { (non- } \\
\text {-weighted) }\end{array}$ & $\begin{array}{c}\mathrm{S}_{\mathrm{w}} \\
\text { (weighted) }\end{array}$ & $\begin{array}{c}\mathrm{S}_{\mathrm{n}} \text { (non- } \\
\text {-weighted) }\end{array}$ & $\begin{array}{c}\mathrm{S}_{\mathrm{w}} \\
\text { (weighted) }\end{array}$ & $\begin{array}{c}\mathrm{S}_{\mathrm{n}} \text { (non- } \\
\text {-weighted) }\end{array}$ & $\begin{array}{c}\mathrm{S}_{\mathrm{w}} \\
\text { (weighted) }\end{array}$ \\
\hline Infrastructure & -0.30 & -3.59 & -0.28 & -3.47 & -0.23 & -2.28 \\
\hline Quickness & -0.65 & -15.67 & -0.62 & -17.05 & -0.67 & -15.43 \\
\hline Reliability & -0.76 & -18.07 & -0.69 & -18.84 & -0.74 & -20.62 \\
\hline Certainty & -0.58 & -13.44 & -0.57 & -14.03 & -0.64 & -15.98 \\
\hline Empathy & -0.35 & -4.93 & -0.36 & -3.48 & -0.36 & -4.97 \\
\hline & $\begin{array}{l}\text { Total } \\
\text { SERVQUAL } \\
=-0.518\end{array}$ & $\begin{array}{l}\text { Total } \\
\text { SERVQUAL } \\
=-11.318\end{array}$ & $\begin{array}{l}\text { Total } \\
\text { SERVQUAL } \\
=-0.505\end{array}$ & $\begin{array}{l}\text { Total } \\
\text { SERVQUAL } \\
=-11.048\end{array}$ & $\begin{array}{l}\text { Total } \\
\text { SERVQUAL } \\
=-0.526\end{array}$ & $\begin{array}{l}\text { Total } \\
\text { SERVQUAL } \\
=-11.856\end{array}$ \\
\cline { 2 - 7 }
\end{tabular}

Table 6 General SERVQUAL indicator non-weighted and weighted for individual areas of the Świętokrzyskie voivodeship $(N=191)$ in 2015, 2016 and 2017

\begin{tabular}{|l|c|c|c|c|c|c|}
\hline \multirow{2}{*}{ Areas } & \multicolumn{2}{|c|}{2015} & \multicolumn{2}{c|}{2016} & \multicolumn{2}{c|}{2017} \\
\cline { 2 - 7 } & $\begin{array}{c}\mathrm{S}_{\mathrm{n}} \text { (non- } \\
\text {-weighted) }\end{array}$ & $\begin{array}{c}\mathrm{S}_{\mathrm{w}} \text { (wei- } \\
\text { ghted) }\end{array}$ & $\begin{array}{c}\mathrm{S}_{\mathrm{n}} \text { (non- } \\
\text {-weighted) }\end{array}$ & $\begin{array}{c}\mathrm{S}_{\mathrm{w}} \text { (wei- } \\
\text { ghted) }\end{array}$ & $\begin{array}{c}\mathrm{S}_{\mathrm{n}} \text { (non- } \\
\text {-weighted) }\end{array}$ & $\begin{array}{c}\mathrm{S}_{\mathrm{w}} \text { (wei- } \\
\text { ghted) }\end{array}$ \\
\hline Infrastructure & -0.24 & -2.61 & -0.22 & -2.40 & -0.18 & -1.80 \\
\hline Quickness & -0.63 & -13.77 & -0.57 & -12.62 & -0.68 & -18.17 \\
\hline Reliability & -0.60 & -16.08 & -0.68 & -19.66 & -0.66 & -18.87 \\
\hline Certainty & -0.67 & -16.84 & -0.67 & -17.69 & -0.61 & -15.33 \\
\hline Empathy & -0.39 & -5.84 & -0.30 & -3.63 & -0.28 & -2.70 \\
\hline & $\begin{array}{l}\text { Total } \\
\text { SERVQUAL } \\
=-0.504\end{array}$ & $\begin{array}{l}\text { Total } \\
\text { SERVQUAL } \\
=-11.022\end{array}$ & $\begin{array}{l}\text { Total } \\
\text { SERVQUAL } \\
=-0.489\end{array}$ & $\begin{array}{l}\text { Total } \\
\text { SERVQUAL } \\
=-11.162\end{array}$ & $\begin{array}{l}\text { Total } \\
\text { SERVQUAL } \\
=-0.477\end{array}$ & $\begin{array}{l}\text { Total } \\
\text { SERVQUAL } \\
=-11.374\end{array}$ \\
\cline { 2 - 7 }
\end{tabular}


The value of all indicators is not huge and it is at the threshold point of .00 , which means the lack of the quality optimum. Hence the conclusion that the insurance premium, which insurance company clients pay for the environmental insurance service, as well as the process of the elimination of damage, does not fully satisfy them and thus does not meet their needs. Therefore, customers also incur higher costs for lower quality than expected. In all the surveyed voivodeships there is the "lack of quality." However, the highest indicator of a lack of satisfaction was recorded in the Podkarpackie voivodeship (compared to 2015 it has fallen by 1.5 percentage points). In contrast, in the other two analysed voivodeships there was an increase in satisfaction, and so: in the Małopolskie voivodeship compared to 2015, there has been an increase of 5.2 percent, and in the Świętokrzyskie province of 5.4 percent.

By comparing non-weighted SERVQUAL indicators with the weighed ones, the weighted values of the assessed indicators in all voivodeships increase. It can be concluded that general SERVQUAL indicators: non-weighted $(S n)$ and weighted $(S w)$ confirm that the quality level of property insurance services in the surveyed insurance companies in the Podkarpackie, Świętokrzyskie and Małopolskie voivodeships differs from the expectations of customers, and thus does not meet their needs. The values of these indicators inform that the discrepancies in the quality of the desired environmental insurance service quality are not too high. However, it is worrying that in the period analysed, i.e. in 2015, 2016 and 2017, it remained practically at the same level.

\section{Conclusions}

The conducted analyses relating to the availability and quality assessment of property insurance services within the scope of protection against ecological risks let one come to the following conclusions:

1. Although there has been a new socio-economic system in Poland for over 20 years, on the market there are still insufficient insurance programs protecting the property and life of customers of insurance companies, and there is a lack of sufficient mechanisms and procedures connected with the elimination of ecological damage.

2. One of the basic sources of financing the creation of risks for environmental damage related to environmental protection is the collateral in the form of a bank loan (mortgage) and purchase of insurance coverage (comprehensive insurance - from fire and other random events).

3. The results indicate (the analysis of three voivodeships of the south-eastern Poland) the reluctance of home-owners to conclude insurance contracts or 
to continue them. It can be presumed that this situation is present all over Poland.

4. The SERVQUAL indicators in all the analysed voivodeships, consisting of the personnel-related areas and personal contact of employees of the insurance company with the client - took the first three places. These were consecutively: reliability, quickness and credibility of the insurance service. Empathy was the fourth. On the other hand, a group of statements referring to the material aspects of the provision of property insurance services was considered by clients to be the highest-assessed dimension of the quality of service.

5. The value of all indicators is not huge and is below the proposed critical point of .00 , i.e. the lack of the quality optimum. This means that the insurance premium paid by the insurance company clients for the service offered and the claims handling process do not fully satisfy them and thus do not meet their needs.

6. Insurance company clients incur higher costs for the lower quality than expected. Therefore, in all the examined voivodeships we are dealing with the "poor-quality" problem. The largest indicator of the lack of satisfaction was noted in the Podkarpackie voivodeship. However, in the other two analysed voivodeships there was an increase in satisfaction.

Further research will allow for more precisely assessing the following: first, the capacity of the Polish insurance market in terms of package contracts related to environmental protection, second, increasing the awareness of the risks posed by this type of risk for customers of insurance companies, and third, to what extent Poland is prepared to implement solutions that already exist, not only in the world but also in Europe.

\section{References}

Adamowicz, M. (2004). Integration of agricultural and environmental policies as a way for sustainable development of rural areas, CEESA - Central and Eastern European Sustainable Agriculture. Retrieved from: www.ceesa.de/NitraPapers/Adamowicz.pdf [accessed: 26.07. 2018].

Bailey, N.J., Swinerd, G.G., Lewis, H.G., \& Crowther, R. (2010). Global vulnerability to near-Earth object impact. Risk Management, 12(1), 31-53.

Bohdanowicz, P. (2006). Turystyka a świadomość ekologiczna. Toruń: Wydawnictwo Adam Marszałek.

Broda, J., \& Pluskiewicz, W. (1993). Świadomość ekologiczna i wartościowanie przyrody. Gliwice: Habex-Universum.

Burger, T. (2000). Świadomość ekologiczna społeczeństwa polskiego u rogu XXI w. Raport 1: Warszawa. 
Doś, A. (2007). Perspektywy rozwoju ubezpieczeń ekologicznych w Polsce. In M. Marcinkowska, S. Wieteska (eds), Harmonizacja bankowości i ubezpieczeń w skali narodowej i europejskiej. Warszawa: Difin.

Fiedor, B. (2007). Ekonomiczne aspekty odpowiedzialności ekologicznej i jej ubezpieczenie doświadczenia międzynarodowe i polskie perspektywy. In J. Malewski (ed.), Szkody w środowisku, odszkodowania i zabezpieczenia roszczeń na terenach górnictwa odkrywkowego. Wrocław: Oficyna Wydawnicza Politechniki Wrocławskiej.

Frątczak, J. (2001). Świadomość ekologiczna dzieci, młodzieży i dorosłych $w$ aspekcie edukacji szkolnej i nieszkolnej. Bydgoszcz: Wyższa Szkoła Pedagogiczna.

Fudali, I. (2002). Kultura ekologiczna młodzieży. Kielce: Wydawnictwo Akademii Świętokrzyskiej.

Górka, K., Poskrobko, B., \& Radecki, W. (1998). Ochrona Środowiska, problemy społeczne, ekonomiczne i prawne. Warszawa: Polskie Wydawnictwo Ekonomiczne.

Hadzigeorgiou, Y., \& Skoumios, M. (2013). The development of environmental awareness through school science: Problems and possibilities. International Journal of Environmental and Science Education, 8(3), 405-426.

Kalinowska, A. (2013). Czy człowiek współczesny zdolny jest do dialogu ze środowiskiem? Biuletyn Polskiego Komitetu ds. UNESCO.

Kiełczewski, D. (1999). Ekologia społeczna. Białystok: Ekonomia i Środowisko.

Kłos, L. (2015). Świadomość ekologiczna ptaków - przegląd badań. Studia i Prace Wydziału Nauk Ekonomicznych i Zarządzania Uniwersytetu Szczecińskiego, 2(42), 37-42.

Krajewski, P. (2018). Nowe spojrzenie na ochronę środowiska i prawa człowieka z perspektywy jego potrzeb, Problemy Ekorozwoju, 13(2), 27-32.

Labatt, S., \& White, R. (2002). Environmental Finance. A Guide to Environmental Risk Assessment and Financial Products. New Jersey: John Wiley and Sons, Inc., Hoboken.

Łabno, Z. (1995). Ubezpieczenia ekologiczne. Wybrane zagadnienia. Prace Naukowe/Akademia Ekonomiczna w Katowicach, (67), 1-67.

Maśniak, D. (2003). Ubezpieczenia ekologiczne. Kraków: Zakamycze.

Papuziński, A. (2006). Świadomość ekologiczna w świetle teorii i praktyki (Zarys politologicznego modelu świadomości ekologicznej). Problemy Ekorozwoju, 1(1), 33-40.

Parasuraman, A., Zeithaml, V.A., \& Berry, L.L. (1985). A conceptual model of service quality and its implications for future research. Journal of Marketing, (49), 41-50.

Poskrobko, B. (ed.) (2007). Zarządzanie środowiskiem. Warszawa: Polskie Wydawnictwo Ekonomiczne.

Przybytniowski, J.W., \& Pacholarz, W.M. (2016). Bezpieczeństwo ekologiczne w usłudze ubezpieczeniowej. Ekonomika i Organizacja Przedsiębiorstwa, (2/793), 42-47.

Przybytniowski, J.W. (2013a). Financing instrument for risks managing. Polish experience. Business: Theory and Practice, 14(3), 217-227.

Przybytniowski, J.W. (2013b), Konkurencyjność rynku pośrednictwa ubezpieczeniowego $w$ Polsce, Warszawa: Wydawnictwo Menedżerskie PTM.

Sederevičiūtè-Pačiauskienè, Ž., Žilinskaitè-Vytienè, V., \& Valantinaitè, I. (2017). A three-dimensional approach in education for sustainable future. Problems of Sustainable Development, 12(1), 63-69.

Sordyl, G., \& Płonka, M. (2010). Ubezpieczenia ekologiczne, jako metoda finansowania ryzyk w górnictwie. Wiadomości Ubezpieczeniowe, (1), 95-97.

Biblia Tysiąclecia. Pismo Święte Starego i Nowego Testamentu (2003). Rdz 1, 26-27. Poznań: Wydawnictwo Pallottinum.

Biblia Tysiąclecia. Pismo Święte Starego i Nowego Testamentu (2003). Rdz. 3, 17-18. Poznań: Wydawnictwo Pallottinum. 
Wódz, J., \& Wódz, K. (1993). Społeczne znaczenie świadomości ekologicznej. In J. Wódz (ed.), Zagrożenia ekologiczne. Warunki życia; Wizje przyszłości, Katowice: Śląsk Sp. z o.o., pp. 7-19.

www.slownik-online.pl/kopalinski/5277E06541747D8FC12565B500672F7C.php [acessed: 10.07.2018].

Zecha, S. (2010). Environmental knowledge, attitudes and actions of Bavarian (Southern Germany) and Asturian (Northern Spain) adolescents. International Research in Geographical and Environmental Education, 19(3), 227-240.

Note about the Author

JarosŁaw Wenancjusz Przybytniowski - PhD in Economics (2000) of the Institute of Management, Faculty of Management and Administration at the Jan Kochanowski University in Kielce. Employment: assistant professor at the Jan Kochanowski University in Kielce (2002). His scientific achievements include: 3 original monographs, 3 co-authored monographs; 105 scientific articles published in national and foreign scientific journals. A participant of 11 foreign scientific internships together with invitation lectures in England and Germany. Active participation in national (62), international (31) and foreign (17) conferences and seminars. Conducting scientific research: Nine domestic and foreign research projects. Awards received: in 1998-1999 (3) and in 2012 the award named after prof. Tadeusz Sangowski (1). Organizer of postgraduate studies: Project management. Cooperation with national, international and foreign scientific-research and economic institutions. Research interests: financial market, including insurance market. 
